Pengaruh Budaya Luar terhadap Perkembangan

Masyarakat Bulungan: Studi Pendahuluan 117-129

\title{
PENGARUH BUDAYA LUAR TERHADAP PERKEMBANGAN MASYARAKAT BULUNGAN: STUDI PENDAHULUAN*
}

\author{
Nugroho Nur Susanto**
}

\author{
Balai Arkeologi Banjarmasin, Jalan Gotong Royong II, RT 03/06, Banjarbaru 70711, Kalimantan Selatan; \\ Telepon (0511) 4781716; Facsimile (0511) 4781716
}

Artikel masuk pada 26 Agustus 2012

Artikel selesai disunting pada 23 September 2011

\begin{abstract}
Abstrak. Bulungan terletak pada kawasan geografis yang dilalui oleh Sungai Kayan. Sungai tersebut adalah urat nadi lalu lintas yang sangat penting dalam melancarkan interaksi manusia, budaya, dan perdagangan pada masa lampau. Intensitas interaksi dengan kebudayaan dari luar dan ekskpansi politiklah yang pada akhirnya mendorong adanya perubahan-perubahan pada aspek sosial-budaya, ideologi, dan politik. Kajian ini dilakukan melalui studi pustaka dan pengamatan langsung di lapangan. Hasil kajian menunjukkan kedatangan Islam telah mengubah perspektif sosial-budaya masyarakat asli Bulungan dan sistem pemerintahan yang berlandaskan Islam. Di lain pihak, kedatangan Belanda di Bulungan dilandasi oleh tujuan eksploitasi dan penguasaan tambang minyak bumi, yang akhirnya melemahkan kekuasaan politik Kaselutanan Bulungan.
\end{abstract}

Kata kunci: Makulit, Kayan, Kenyah, Tunjung, Tidung, Sungai Kayan, religi asli, Islam, imperialisme, Belanda, Brunei

Abstract. THE INFLUENCE OF FOREIGN CULTURES ON THE DEVELOPMENT OF BULUNGAN'S SOCIETY: PRELIMINARY STUDIES. Bulungan lies in the geographic region sliced by the Kayan River. The river is the vital traffic artery to accelerate interaction of humans, cultures and trades in the past. The intensity of interaction with foreign cultures and political expansion ultimately pushed the changes in the socio-cultural, ideological, and political aspects of the Bulungan people. The research was conducted by literature study field observations. The results indicate the arrival of Islam has changed the socio-cultural perspective of indigenous people of Bulungan and convert the government system which based on Islam. On the other hand, the arrival of the Dutch in Bulungan was derived from the intention of exploiting and controling the petroleum mining, which ultimately had weaken the political power of Kesultanan Bulungan.

Keywords: Makulit, Kayan, Kenyah, Tunjung, Tidung, Kayan River, indigenous religion, Islam, imperialism, Dutch, Brunei

* $\quad$ Makalah pernah diseminarkan dalam Evaluasi HasilPenelitian Arkeologi di Solo pada tanggal 3-7 September 2012

** Penulis adalah Peneliti Madya pada Balai Arkeologi Banjarmasin, email: nugi_balarbjm@yahoo.com 
Pengaruh Budaya Luar terhadap Perkembangan Masyarakat Bulungan: Studi Pendahuluan 117-129

\section{A. Pendahuluan}

Masyarakat Bulungan adalah mereka yang diikat oleh satu keturunan yang berasal dari etnis Hupan atau Dayak Kayan, yang telah bercampur dan dipengaruhi oleh tradisi agama Islam dan bernaung di bawah institusi kekuasaan Kesultanan Bulungan. Gelar bagi bangsawan keturunan Kesultanan Bulungan adalah Datu', misalnya Datu' Mansyur dan Datu' Makmun. Pusat pemukiman keturunan Sultan Bulungan berada tidak jauh dari aliran Sungai Kayan.

Sungai Kayan $(576 \mathrm{Km})$ mengalir di tiga wilayah kabupaten, yaitu Kabupaten Malinau, Kabupaten Bulungan, dan Kabupaten Tana Tidung (Tim Badan Pusat Statistik Kabupaten Bulungan 2010, 3). Peran penting Sungai Kayan sebagai jalur transportasi sangat terasa pada saat belum dikenalnya jalan darat sebagai penghubung antara daerah luar pulau dengan daerah pedalaman. Berkat Sungai Kayan terjadilah perkenalan antarkomunitas, interaksi antarbudaya, dan pertukaran hasil bumi. Aktivitas kemajuan budaya pun sangat tergantung dengan intensitas interaksi manusianya dan usaha penaklukan alam. Lebatnya hutan belantara, derasnya arus, dan banyaknya riam, khususnya di bagian hulu, setidaknya telah menghambat arus transportasi. Ini merupakan tantangan alam yang menjadi salah satu faktor menghambat, sehingga masuknya arus budaya dari luar lambat..

Folklore asal-usul nenek moyang masyarakat Bulungan memberikan gambaran bahwa perubahan itu terjadi karena dua atau lebih komunitas bertemu, yaitu komunitas terdahulu yang asli (indegeneus) dan pendatang. Jauh sebelum kemunculan Kerajaan Bulungan ada legenda mengenai nenek moyang masyarakat Bulungan. Berdasarkan cerita rakyat, masyarakat Bulungan berasal dari etnis Kayan yang menyebut kelompoknya sendiri sebagai etnis Hupan. Semula, mereka bermukim di Long Payang, yaitu salah satu cabang dari Long Pujungan yang sekarang menjadi wilayah administrasi Kabupaten Malinau. Perkampungan itu dulunya hanya berupa dua buah Lamin (rumah panjang) yang dihuni oleh sekitar 100 orang. Dalam komunitas ini hiduplah sepasang suami-istri, yang bernama Kuanyi. Suami-istri ini sudah lama menginginkan anak, tetapi belum juga dikaruniai anak. Pada saat berburu, ia dikejutkan oleh suara tangisan bayi laki-laki yang berasal dari ruas bambu besar (betung) yang kemudian beri nama Jauwiru, dan seorang bayi perempuan yang berasal dari sebutir telur yang kemudian diberi nama Lemlai Suri. Sebagai pasangan suami-istri yang sekaligus menjadi tetua kampung, hal ini tentu sangat membahagiakan. Kedua anak yang didapat secara gaib itu kelak dijodohkan dan memimpin komunitasnya. Pada saat Kuwanyi meninggal Jauwirulah penggantinya. Pasangan Jauwiru dan Lemlai Suri dikaruniai anak yang bernama Paran Anyi. Selanjutnya, dalam perkawinannya, Paran Anyi tidak memiliki putra laki-laki, tetapi memiliki anak perempuan yang bernama Lahai Bara, yang kemudian dinikahi oleh Wan Paren ${ }^{1}$ (Anonim 1976). Kisah lainnya menyebutkan bahwa Lahai Bara menikah dengan Jau Anyi. Tokoh Lahai Bara, menjadi awal perubahan dimana ia berusaha keluar dari komunitasnya.

Jauwiru meninggalkan tiga benda magis yang perlu selalu dipelihara, yaitu (1) dayang; (2) kedabang atau penutup kepala; dan (3) kerkepan atau alat untuk mengambil padi (ani-ani). Lahai berusaha mendapatkan dan membawanya ke hilir. 
Pengaruh Budaya Luar terhadap Perkembangan

Masyarakat Bulungan: Studi Pendahuluan 117-129

Sebelum meninggal Jau Anyi berpesan untuk membawa lungun ke hilir Sungai Payang. Hal tersebut dicegah oleh saudara-saudaranya. Namun, karena suatu amanat maka pesan tetap dilaksanakan. Lahai Bara mengikuti arus sungai menuju hilir, atas kesaktiannya muncul pulau di tengah sungai yang disebut busang manyun (Pulau Hanyut). Tidak jauh dari Pulau Hanyut, di sebelah hilir terdapat peninggalan yang seperti "menhir", konon peninggalan ini adalah makam Lahai Bara ${ }^{2}$ (Foto 1).

Lebih lanjut diceritakan, dari perkawinan Lahai Bara dan Wan Paren lahirlah Si Barau dan seorang putri bernama Simun Luwang. Simun Luwanglah yang membawa lungun Lahai Bara, sehingga dimakamkan di Long Pelban. Hal tersebut mendapat tantangan dari Si Barau, saudaranya. Oleh karena itu, keturunan Simun Luwang (masyarakat Bulungan) tidak boleh mengujungi Makam Lahai Bara di Long Pelban. Hal tersebut masih dipercaya hingga saat ini (Anonim 1976).

Simun Luang yang dianggap telah meninggalkan komunitasnya, terus menuju ke arah hilir hingga sampai di Baratan. la pun menikah dengan Sadang. Dari perkawinan ini, lahirlah tokoh Asung Luwang. Pada saat Asung Luwang beranjak dewasa, ada seorang bangsawan Brunei bernama Datuk Mencang, yang saat itu sedang menyusuri Sungai Kayan dan berlabuh. Datuk Mancang berhasil memperistri Asung Luwang. Di komunitas itu, Datuk Mencang membangun sistem pemerintahan yang teratur dan maju. Oleh karena itu, Datuk Mencang (1555-1594) dianggap sebagai peletak dasar Kesultanan
Bulungan. Raja-raja awal ini kemudian bergelar Wira (ksatria), pemerintahan yang mulai teratur ini dilanjutkan oleh menantu Datuk Mencang, bernama Singa Laut, karena perkawinan Datuk Mencang dengan Asung Luwang tidak dikaruniai anak laki-laki. Datu Singa Laut konon berasal dari Zulu (Filipina), memerintah dari tahun 1594-1618. Pengaruh Islam pun dominan dan menguat ke dalam sistem pemerintahan, dan pada akhirnya penguasa tertinggi bergelar sultan.

\section{B. Situasi Sosial Budaya di Daerah Aliran Sungai Kayan}

Perubahan dalam suatu komunitas akan terjadi disebabkan oleh dua hal. Pertama, adanya inovasi yaitu penciptaan, modifikasi atau peningkatan daya cipta, dan kreasi yang terjadi di dalam internal kelompok masyarakat. Jenis faktor perubahan ini dimungkinkan akibat dari hasil olah budi, pemikiran, dan perilaku yang berulang-ulang, baik secara individu, maupun secara komunal. Proses ini terjadi di dalam kelompok mereka sendiri. Kedua, proses difusi atau penyebaran kebudayaan, yaitu perubahan yang terjadi akibat pengaruh eksternal, yang kemungkinan disebabkan oleh kedatangan atau pergaulan dengan komunitas lain. Pengaruh ini dapat terjadi baik secara individu atau kelompok. Perubahan dapat secara sepihak ataupun terjadi secara timbal balik antarmasyarakat dengan budaya atau komunitas lain. Hal ini dapat terjadi dengan cara damai atau pun akibat invasi. Penaklukan atau perebutan

2 Di Long Pelban, wilayah Kecamatan Peso, di tepian aliran Sungai Kayan, Tim Balai Arkeologi Banjarmasin pada tahun 2012 masih dapat menemukan batu tegak dua buah, tetapi dalam keadaan terpenggal. Menurut narasumber, pada 1990an di depan batu tegak ini terdapat dua buah patung. Pada saatsurvei dilakukan, kedua patung tersebut telah hilang karena dicuri. 
Pengaruh Budaya Luar terhadap Perkembangan Masyarakat Bulungan: Studi Pendahuluan 117-129

suatu daerah kekuasaan sering terjadi di masyarakat pada zaman dahulu dan menjadi salah satu bentuk interaksi.

Hasil dari proses inovasi dan difusi ini berpengaruh dalam berbagai aspek budaya dan cara hidup. Perubahan itu misalnya dalam hal tingkah laku kehidupan sehari-hari, kebiasaan pola konsumsi, dan dalam berpakaian, hingga pada hal yang lebih kompleks. Pengaruh budaya luar telah mengubah jenis makanan pokok masyarakat yang semula sagu hutan menjadi beras gunung. Dulu, masih banyak tanaman sagu hutan, umbut tanaman tertentu yang biasa dikonsumsi, ikan air tawar, dan binatang buruan. Berbeda dengan sekarang, sagu hanya dikonsumsi oleh sebagian kecil masyarakat, misalnya komunitas Dayak Berusu, di daerah Sekatak. Pada saat ini, sagu tidak lagi menjadi makanan pokok, tetapi hanya sebagai makanan tambahan saja. Hal yang lebih kompleks terlihat pada perubahan tradisi dan agama, yaitu perubahan yang dibawa oleh para penyiar agama Islam dan kedatangan bangsa Barat yang membawa ajaran agama Nasrani.

Sosial budaya masyarakat DAS (daerah aliran sungai) Kayan banyak mengandalkan hasil bumi dan kondisi kekayaan alamnya. Dalam perdagangan tentu membutuhkan lokasi tempat untuk bertemu, antara pedagang dan pembeli atau dua pihak yang tukarmenukar komoditas (barter), sedangkan sarana transportasi yang memadai sulit dipenuhi. Dengan kondisi sungai yang tidak mendukung ini, sektor pertanian dan perladangan mendominasi cara hidup dan mata pencaharian masyarakatnya. Namun demikian, hingga saat ini belum ada data ertanggalan yang menguatkan kapan terjadi perubahan pola konsumsi makanan pokok, dari sagu gunung ke makanan pokok beras di DAS Kayan. Namun demikian, cerita-cerita rakyat dapat dihubungkan dengan perkenalan awal domestifikasi padi melalui alat-alat pertanian, misalnya tugal, ani-ani, dan lesung, serta lumbung padi. Pada saat Lahai Bara meninggalkan saudara-saudaranya, ada tiga benda penting yang dibawa, yaitu ani-ani, dayung, dan topi pandan, selain lungun orang tuanya ${ }^{3}$. Benda-benda demikian umumnya sarat dengan cerita mistik, serta dihormati.

Adapun perubahan juga dirasakan terhadap jenis bahan pakaian mereka, yang semula berbahan serat kulit kayu menjadi bahan sejenis kain. Hal ini masih dapat dirunut dari laporan-laporan perjalanan orang Belanda dan orang Inggris sekitar abad 18 Masehi (Carl Box dan Wallace). Pada acara adat, mereka kadang masih menggunakan pakaian berbahan serat kayu hingga sekarang. Dahulu, kebutuhan akan papan atau perumahan biasanya dipenuhi dalam bentuk bangunan komunal berupa rumah lamin, sebutan masyarakat adat di Kalimantan Timur, atau rumah betang, sebutan rumah panjang pada masyarakat adat di Kalimantan Tengah atau rumah panjang untuk sebutan rumah komunal bagi masyarakat adat di Kalimantan Barat. Bentuk bangunan rumah tersebut terkait dengan faktor keamanan, kebersamaan, dan jiwa gotong royong dalam

Ani-ani merupakan alat memotong padi, walau kurang efisien dibandingkan sabit, tetapi sangat popular di Asia Tenggara. Berdasarkan cerita rakyat, alat ini lebih berkenan bagi Dewi Sri (Dewi Padi). Di samping itu, ani-ani memiliki fungsi praktis, khususnya untuk padi di perbukitan. Petani dapat menuai batang-batang padi yang telah masak dan membiarkannya, hingga waktu tertentu sesuai keinginan (Reid 2011, 32-33) 
Pengaruh Budaya Luar terhadap Perkembangan

Masyarakat Bulungan: Studi Pendahuluan 117-129

mengatasi permasalahan keseharian, pekerjaan berkala, misalnya dalam perladangan, pertanian dan ritual upacara. Dahulu, penyerangan antarkelompok merupakan hal biasa dan sering terjadi. Rumah lamin dibuat panggung dengan tiang tinggi dan tangga rumah pun dibuat tidak permanen sehingga dapat dipindahkanpindahkan. Selain itu, bangunan panggung juga bertujuan untuk menghindari serangan binatang buas dan menghindari jangkauan tombak musuh. Ruang dalam rumah panjang dibuat berderet untuk mempermudah pengorganisasian pekerjaan secara bersama-sama, baik dalam berburu, pengerjaan sawah atau huma maupun pelaksanaan upacara adat. Pada kegiatan test pit penelitian eksplorasi di Long Ampung, ditemukan juga sisa-sisa lamin (Gunadi 2006). Sementara itu, penelitian eksplorasi pada tahun 2012 ini mendapatkan informasi mengenai lamin yang terdapat di Long Pelban, di wilayah Kecamatan Peso' dan di Bukit Pejangan, berdekatan dengan Gua Pejangan yang menjadi lokasi penguburan masyarakat Dayak Kayan. Hingga saat ini, di seberang Bukit Pejangan ini masih banyak penduduk Kayan yang bermukim di Desa Mara, Kecamatan Tanjung Palas Barat.

Selain pengaruh terhadap aspek kehidupan pokok sehari-hari, pengaruh dari luar atau komunitas lain juga terjadi pada sesuatu yang sulit berubah, yaitu sistem religi, kepercayaan atau agama.

\section{Religi di Daerah Aliran Sungai Kayan}

Religi atau kepercayaan merupakan aspek budaya yang paling penting, sekaligus sulit untuk berubah. Kepercayaan memiliki kedudukan yang penting, karena unsur budaya ini akan mewarnai dalam segala kegiatan dan tingkah laku dalam kehidupan sehari-hari atau dalam upacara-upacara daur hidup. Namun demikian, dengan cara damai dan perjalanan waktu yang panjang, lambat laun aspek religi atau kepercayaan ini bisa berubah. Perubahan ini tentu tidak serta merta dan menyeluruh, tetapi bersifat sporadis dan parsial. Data arkeologi menunjukkan hal-hal demikian. Pada situasi tertentu unsur religi asli, kadang muncul dan mewarnai dalam kehidupan sehari-hari.

Pada sekitar 1930, Schneeberger mengunjungi daerah Long Pujungan, Long Pelung, dan Long Brini dalam rangka survei geologi. Dalam survei ini, Schneeberger melaporkan adanya urn-dolmen. Pada tahun 1987, Baier melaporkan peninggalan kubur batu di Long Pujungan, yang sekarang masuk dalam wilayah Kabupaten Malinau, serta sejumlah sarkofagus dan tempayan dolmen di daerah Apo Kayan (Sellato 1999, 397-398). Mulai tahun 1991, hingga 1996 Bernard Sellato mengadakan beberapa survei dengan pendekatan multidisipliner di Long Pujungan, Kerayan, dan hulu Sungai Kayan. Di antaranya melibatkan Karina Arifin dan beberapa arkeolog dari Universitas Indonesia. Penelitian di Apau Ping, daerah Sungai Lurah menemukan situs kubur batu, dolmen, menhir, dan peninggalan penting lainnya. Di Kecamatan Kerayan, Sellato dan Karina menemukan situs temuan menhir, pahatan manusia, terupun, dan lesung batu (Sellato 1999, 398-436). Pada aliran Sungai Kayan diperoleh data sebelum orang Kenyah datang, daerah di hulu Kayan ditinggali oleh komunitas masyarakat "kayan". Tercatat ada 45 situs. Tiga puluh situs di antaranya merupakan situs sebelum kedatangan masyarakat Kenyah, dan selebihnya mendapat pengaruh Kenyah, 12 situs kuburan 
Pengaruh Budaya Luar terhadap Perkembangan Masyarakat Bulungan: Studi Pendahuluan 117-129

batu, 5 situs terdapat batu berukir. Berdasarkan informasi dari Bernard Sellato, sebagian situs ini telah dikunjungi oleh Siereverd pada 1929, Tilema pada 1938, Harison pada tahun1959, dan Baier pada tahun 1992. Sellato sendiri mengadakan kunjungan pada 1992 sampai 1999 (Sellato 1999, 403).

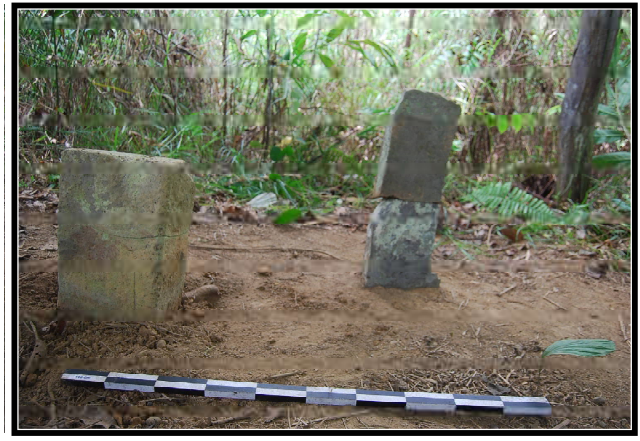

Foto 1. Makam Lahai Bara di hulu Long Pelban, Kecamatan Peso (dok. Balai Arkeologi Banjarmasin 2012)

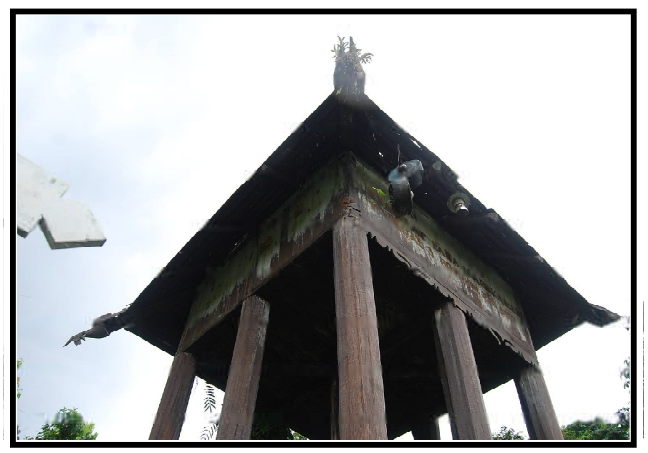

Foto 3. Salung Ipui di Desa Long Lejuh Kecamatan Peso (dok. Balai Arkeologi Banjarmasin 2012)
Pada tahun 2006 Gunadi dkk dari Balai Arkeologi Banjarmasin mengadakan survei untuk menemukenali kembali situs yang disebutkan Sellato, antara lain, mengunjungi Lidung Payau, situs Batu Tukung di hulu Sungai Kayan ${ }^{4}$, situs di Long Uro' dan Juman Lawang di Long Nawang (Gunadi 2006, 2-9). Pada survei di Desa Long Ampung, pinggir

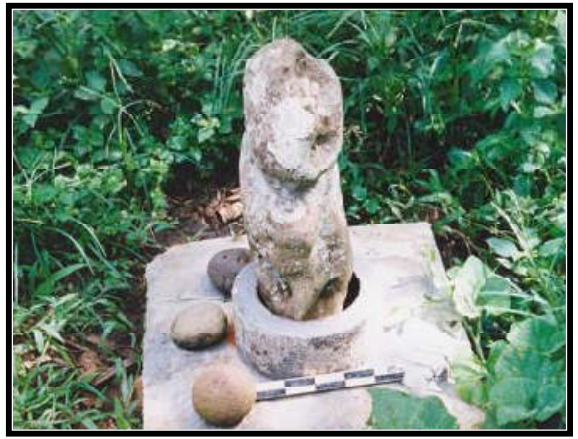

Foto 2. Erang Dau di Desa Long Ampung (dok. Balai Arkeologi Banjarmasin 2006)

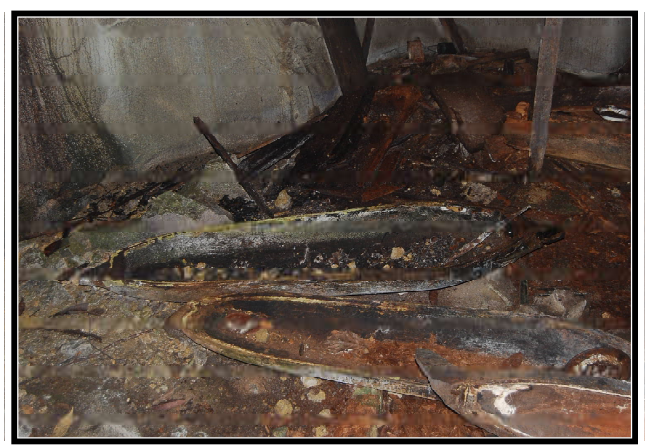

Foto 4. Situasi di dalam Gua Pejangan, Desa Mara, Kecamatan Tanjung Palas Barat (dok. Balai Arkeologi Banjarmasin 2012)

$4 \quad$ Di Lidung Payau, sekarang terkumpul batu pahat dari berbagai situs di sekitarnya, yaitu dari Long Sungan (Gambar manusia dipahat pada batu), dan dari situs Sawah Angen (batu tegak). Hal ini dilakukan untuk mempermudah pengamanan. Batu -batu ini sempat dicuri hingga dibawa ke Tarakan dengan menumpang pesawat terbang, beruntung masih ada petugas yang menyelamatkannya. Dan dikembalikan di Lidung Payau, hulu Sungai Kayan. 
Pengaruh Budaya Luar terhadap Perkembangan

Masyarakat Bulungan: Studi Pendahuluan 117-129

Sungai Kayan, tim menemukan situs yang luput dari pengamatan peneliti terdahulu, yaitu batu Erang Dau. Situs ini oleh masyarakat, sengaja dirahasiakan, karena tidak sejalan dengan iman agama Kristen (dogma gereja), dan dianggap sebuah kepercayaan paganisme. Batu Erang Dau adalah batu tegak, mirip profil manusia, terbuat dari batu monolit, berukuran tinggi 70 -an $\mathrm{cm}$ (sebagai induk), dan disertai tiga batu bulat, seperti telur (sebagai anaknya) dengan diameter bervariasi antara 7-12 cm (Foto 2).

Pada kegiatan eksplorasi peninggalan di DAS Kayan tahun 2012 ini ditemukan dua jenis penguburan di tiga wilayah yang berbeda. Jenis penguburan pertama, menggunakan lungun yang dikumpulkan dalam sebuah rumah-rumahan yang khas, disebut sebagai salung. Sistem penguburan ini ditemukan di Long Gelo dan di Long Lejuh (Foto 3), yaitu di daerah hilir dari Long Pelban, hulu dari Long Bia di wilayah Kecamatan Peso. Lokasi kedua salung tersebut berada di pinggir Sungai Kayan. Menurut informasi penduduk, sistem penguburan ini milik masyarakat adat Dayak Makulit. Bangunan salung ditopang oleh tiang yang berjumlah sembilan buah dan dilengkapi gong sebagai alat penanda. Jenis penguburan yang kedua ditemukan di seberang Desa Mara, di Bukit Pejangan, yaitu penguburan dengan lungun yang diletakkan di dalam gua (Foto 4). Di Gua Pejangan inilah komunitas Dayak Kayan menempatkan lungunlungunnya, tradisi ini masih dilaksanakan hingga 1960-an.

Tidak diragukan lagi bahwa manusia selalu ingin mencari hakekat kehidupan. Hal yang termasuk hakekat dan selalu aktual untuk dipertanyakan adalaha apa tujuan hidup, untuk apa ia hidup, dan atas pertolongan siapa untuk keluar dari kesulitan hidup. Salah satu media penyalurannya tergambar dalam sistem religi, yang diaktualisasikan dengan tradisi megalitik. Dengan demikian, tidak mengherankan jika tradisi megalitik yang hampir tersebar di seluruh dunia menggambarkan sistem religi dan menjawab pertanyaan tersebut. Premis dasar dari setiap religi adalah kepercayaan akan adanya jiwa, sesuatu yang bersifat supranatural, dan kekuatan supernatural. Lebih lanjut, religi mempunyai fungsi di antaranya mengurangi kegelisahan dan menjawab atas hal-hal di luar jangkauan pikirannya, seperti bencana, penyakit, dan kematian (Thomas 1979 vide Prasetyo 2004, 1-3). Komunitas etnis di pedalaman Kalimantan, khususnya daerah aliran Sungai Kayan menggambarkan tradisi religi, antara lain dalam hal pemujaan dan penguburan yang merupakan salah satu aspek upacara daur hidup dan mati. Sellato telah mendeskripsikan berbagai peninggalan dan komunitas yang mendiami daerah utara, antara lain Long Brini, Kayan Mentarang, dan sekitar Long Bahau. Wujud dari gagasan dalam religi diaktualisasikan dalam benda, misalnya dalam bentuk tinggalan megalitik. Sebagai objek yang dipuja, seperti erang dau dan wadah kubur materialisasi dari upacara penguburan.

Pada saat ini, kemudahan transportasi dan keinginan menjelajah ke luar daerah menyebabkan telah terjadi polarisasi penduduk. Selain Dayak Makulit dan Dayak Kayan di sepanjang DAS Kayan, banyak pula komunitas lain, seperti Dayak Kenyah, Dayak Tunjung, dan Tidung. Meskipun demikian, aspek religi di daerah hulu Sungai Kayan relatif kuat dan dipertahankan dari generasi ke generasi sehingga sulit berubah. Pergeseran terjadi sedikit demi sedikit, yaitu dari kepercayaan agama tradisi ke agama 
Pengaruh Budaya Luar terhadap Perkembangan Masyarakat Bulungan: Studi Pendahuluan 117-129

monotheistik, pada sekitar 1970-an semenjak datangnya para misionaris agama Kristen.

Di Long Ampung, wilayah Malinau untuk misi agama mengandalkan transportasi udara, yaitu melalui penerbangan MAF(Mission Aviation Fellowship). Daerah hulu Kayan terdapat banyak jeram, sehingga tidak memungkinkan dikembangkan transportasi sungai, sedangkan transportasi darat sulit dilakukan karena menembus hutan rimba. Wilayah Kecamatan Long Peso', yaitu wilayah di perbatasan antara Kabupaten Malinau dengan Bulungan misi penyebaran agamanya masih memungkinkan menggunakan transportasi sungai. Melalui Gereja Kemah Injil di Long Bia, kepercayaan lama lambat laun digantikan oleh kepercayaan agama Kristen. Peran sungai sebagai jalur transportasi penyebaran kepercayaan baru, rupanya juga dilakukan oleh penyebar agama Islam. Adanya tinggalan batu tegak di Long Pelban, hulu Long Peso' menimbulkan pertanyaan adakah hubungan atau kaitan dengan nisan seperti tradisi Islam? Hal tersebut perlu penelitian lebih lanjut.

Dahulu, Lokasi gereja di Long Ampung merupakan bekas tempat penguburan masyarakat Kayan, mungkin seperti salung, yang didasarkan pada ciri fisik yang disebutkan oleh tetua adat pada saat proses wawancara (Gunadi 2006). Bangunan ini kemudian dihilangkan dan diratakan dengan tanah. Sebagai simbol kemenangan agama baru atas kepercayaan setempat, maka lokasi tersebut yang merupakan puncak sebuah bukit, kemudian diperuntukkan sebagai lokasi gereja. Tidak jauh dari lokasi gereja ini, masyarakat masih menyimpan Erang Dao. Pihak gereja melarang memunculkan kembali kepercayaan lama ini, karena dianggap mencemari keimanan.

\section{Interaksi dengan Pendatang}

Komunitas di daerah jalur perdagangan internasional atau kota pantai, misalnya di Sumatera atau Jawa pada abad 15 Masehi, sudah begitu maju. Perkenalan dan interaksi perdagangan dengan bangsa lain sudah berjalan intensif dan lancar. Berita para musafir dunia pun sering mengabarkan tentang pengalaman mereka dan mendeskripsikan semua yang dilihat. Akan tetapi, lain halnya dengan daerah pedalaman yang hanya dapat ditembus oleh sungai, tidak begitu ramai, berarus deras, dan hampir tidak mempunyai komoditas yang penting, seperti halnya Sungai Kayan.

Reid menyebutkan bahwa periode antara tahun 1450 hingga 1680 adalah kurun perniagaan. Di kawasan Asia Tenggara, interaksi dagang berjalan dengan relatif damai walaupun tidak berarti tanpa peperangan, dan berjalan dengan intensif dalam pemenuhan kebutuhan. Kebudayaan mengalami perkembangan dengan munculnya kota-kota niaga. Akan tetapi, 'revolusi niaga' pada pertengahan abad ke17 Masehi secara radikal merosot, perniagaan internasional kalah dengan monopoli dagang Belanda dan atau Inggris (Reid 2011, 264-278).

Pada kurun niaga tersebut, di Pulau Borneo atau Kalimantan, telah mucul kotakota niaga terpenting, yang berkonotasi dengan institusi kekuasaan, antara lain Brunei, Banjarmasin, Sukadana, dan Kutai (Reid 2011, 12). Kota niaga tetangga yang 
Pengaruh Budaya Luar terhadap Perkembangan

Masyarakat Bulungan: Studi Pendahuluan 117-129

berdekatan dengan wilayah Kalimantan bagian utara adalah Sulu (Filipina) ${ }^{5}$.

Datu Mencang, yang merupakan seorang bangsawan Brunei telah berjasa dalam memajukan peradaban dan mengubah bentuk organisasi sosial yang semula berdasar adat, menjadi sistem pemerintahan yang lebih maju dan rasional. Menurut perkiraan sejarawan tradisional, masa kedatangan dan kemudian memegang tampuk pemerintahan sekitar tahun 1555 hingga 1594, kemudian dilanjutkan oleh menantunya yang bernama Singa Laut. Tokoh Singa laut, seperti halnya Datu Mencang mendapat kekuasaan karena perkawinan. Diceritakan Singa Laut adalah anak dari bangsawan Kerajaan Sulu di Filipina yang menikahi Kenawai Luwang putri dari Datu Mencang dengan Simun Luwang, seorang putri asli Kayan atau etnis Hupan (Anonim 1976, 2).
Awal kedatangan Islam ke Bulungan, diperkirakan telah terjadi ketika pusat pemerintahan berada di Baratan. Hal ini ditandai dengan adanya makam Sultan Amiril Mukminin atau disebut juga sebagai Wira Amir, yang memerintah sekitar tahun 1731-1777 Masehi. Namun demikian, secara resmi pemakaian gelar Sultan dipakai ketika anak dari Wira Amir, yaitu Sultan Muhammad 'Alimuddin naik tahta. Menurut sejarah yang dipercayai masyarakat, pengislaman kerajaan Bulungan tidak lepas dari peran ulama Sayid Abdurrahman bin Abdullah Billfaqih, seorang Ulama dari Hadramaud, yang yang singgah dahulu di Demak.

Datuk Mencang telah berjasa dalam memperbaiki sistem pemerintahan yang bersifat lebih maju, semula mendasarkan pada adat, kemudian berdasar pada pengorganisasian yang turun-temurun. Pusat pemerintahan berada di Baratan, berlangsung

$5 \quad$ Pada abad 14 Masehi institusi kekuasaan di Brunei telah terorganisasi, yaitu dimulai oleh Sultan Muhammad Shah yang memerintah dari tahun 1363 - 1402. Semula ia bernama Alalak Betatar. Berturut-turut digantikan Sultan Abdul Majid Hasan (1402 - 1408), Sultan Ahmad (1408 - 1425), Sultan SharifAli (1425 - 1432), Sultan Sulaiman (1432 - 1485), Sultan Bolkiah (1485 - 1524). Sultan Abdul Kahar (1524 - 1530), dan Sultan Saiful Rizal (1533 - 1581). Pada tahun 1578, Brunei diserang oleh Spanyol di Manila (Sumber: kakniam.wordpres.com/2011/07/28/sejarah-brunei-darusalam). Sedangkan Kesultanan Sulu juga lebih awal muncul, memiliki pemerintahan teratur dan telah mengenal Islam, yaitu sejak abad 13 Masehi. Perkembangan awal agama Islam di Filipina memiliki sejarah panjang, sebagaimana kedatangan Islam ke kawasan Asia Tenggara secara umum, hampir bersamaan di Sumatera dan Jawa. Menurut cendekiawan Muslim Filipina, Ahmed Alonto, berdasarkan bukti-bukti sejarah, Islam datang ke Filipina pada tahun 1280. Muslim pertama yang datang adalah Sherif Macdum (Sharif Karim al-Makhdum) yang merupakan seorang ahli fikih. Kedatangannya kemudian diikuti oleh para pedagang Arab dan pendakwah. Pada mulanya dia tinggal di kota Bwansa, di mana rakyat setempat dengan sukarela membangun masjid dan banyak yang ikut meramaikan masjid. Secara bertahap beberapa kepala suku setempat menjadi Muslim. Kemudian dia juga mengunjungi beberapa pulau lain. Makamnya dipercaya terdapat di Pulau Sibutu. Selain orang Arab, umat Islam India, Iran, dan Melayu datang ke Filipina, menikah dengan penduduk lokal dan mendirikan pemerintahan di kepulauan Filipina. Salah seorang pendiri pemerintahan itu adalah Sherif Abu Bakar, yang berasal dari Hadramaut yang datang ke kepulauan Sulu melalui Palembang dan Brunei. Dia menikah dengan putri Pangeran Bwansa, Raja Baginda, yang sudah beragama Islam. Ayah mertuanya menunjuknya sebagai pewaris. Setelah menggantikan mertuanya, dia menjalankan pemerintahan dengan hukum Islam serta dengan memperhatikan adat istiadat setempat. Dengan demikian, dia bisa disebut sebagai pendiri kesultanan Sulu (Sumber: Suku Moro.wikipedia-bahasa Indonesia, ensiklopedia bebas; diunduh 23 Januari 2013) 
dari Datuk Mencang, hingga Wira Amir atau Sultan Amiril Mukminin. Atas prakarsa sultan ini pula pusat pemerintahan dipindahkan ke Salim Batu. Sultan berikutnya adalah Sultan Muhammad Alimuddin, anak dari Sultan Amiril. Pada saat itu, hubungan sultan dengan penyebaran agama Islam sangat erat, apalagi pengaruh Sayid Abdurrahman bin Abdullah Bilfaqih sangat kuat, dan belakangan banyak ulama dari Arab yang mengajar di daerah Salim Batu. Di antara ulama itu antara lain adalah Syeh Mahgribi. Kedatangan penyiar agama Islam di pantai sisi timur bagian utara

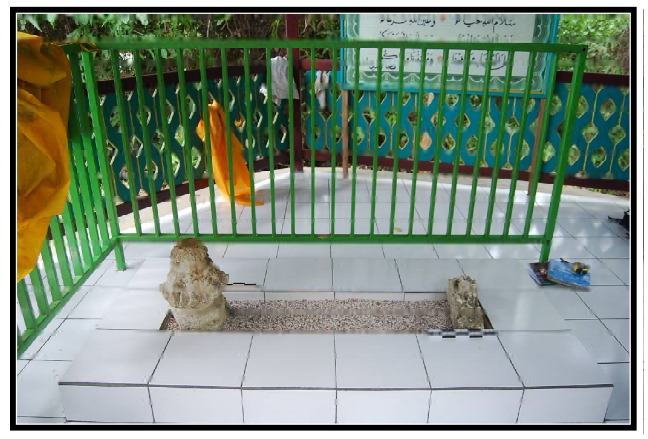

Foto 5. Makam Wira Amir, dianggap sultan pertama memeluk Islam secara resmi (dok. Balai Arkeologi Banjarmasin 2012)

Kalimantan ini diperkirakan ada hubungan erat dengan penyiar agama Islam dari Brunei dan Sulu, yang lebih awal menerima Islam.

Adapun pemindahan pusat kekuasaan dari Salim Batu ke Tanjung Palas terjadi pada masa pemerintahan Sultan Kaharuddin, setelah mengalahkan lanun-lunun dari Sulu. Lambat laun, pengaruh Belanda di Tanjung Selor semakin menguat. Sultan Alimuddin mempunyai dua istri, yang pertama berasal dari putri bangsawan Berau, dan isteri kedua adalah keturunan orang terpandang dari

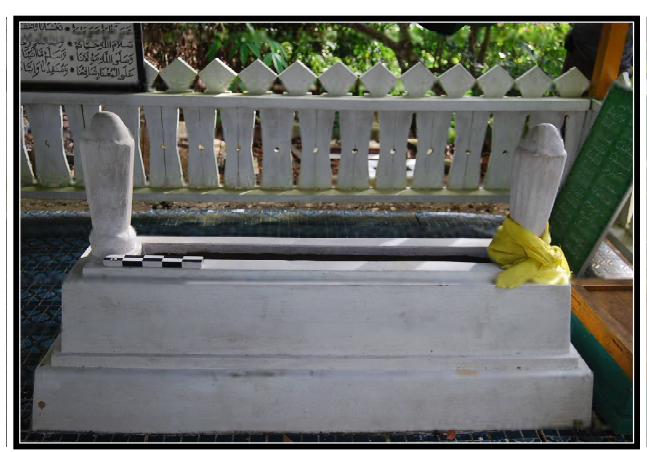

Foto 6. Makam Sayid Abdurrahman bin Abdullah Bilfaqih, meninggal 1820 Masehi (dok. Balai Arkeologi Banjarmasin 2012)

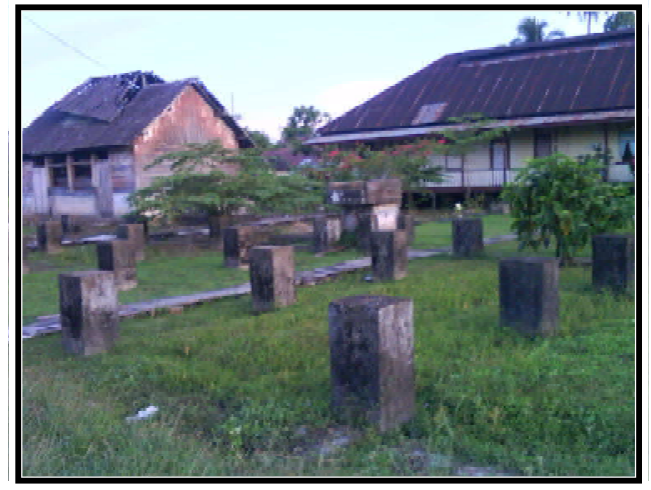

Foto 7. Sisa-sisa rumah Belanda di Tanjung Selor (dok. Zarkasi 2000)

Tidung. Keturunan Sultan Alimuddin dengan putri dari Berau yang bernama Pengian Intan adalah Sultan Muhammad Kaharuddin, yang memerintah tahun 1817-1861, dan pemerintahan kedua 1866-1873. Hasil perkawinan Sultan Alimuddin dengan putri dari Tidung yang bernama Aji Aisyah adalah Sultan Khalifatul Alam Muhammad Adil, yang memerintah pada 1873-1875. Periode pemerintahan antara tahun 1862 hingga 1866 dipegang oleh Sultan Jalaluddin yang merupakan anak dari Sultan Muhammad Kaharuddin. 
Pengaruh Budaya Luar terhadap Perkembangan

Masyarakat Bulungan: Studi Pendahuluan 117-129

Pada abad ke-15 Masehi, penjelajahan bangsa Spanyol dan Portugis telah sampai di Kepulauan Asia Tenggara. Pada tahun 1578, Brunei diserang Spanyol yang telah kokoh menancapkan hegemoninya di Manila, Filipina. Interaksi antarbangsa tersebut telah membuat rasa saling curiga, dan membuat relasi hubungan antarperadaban terganggu, bahkan imbas terburuk terjadi dalam suatu institusi internal kekuasaan seperti Kesultanan Bulungan. Para bangsawan memiliki hubungan dengan bangsa asing di luar komunitasnya, yang sekiranya dapat menyokong hegemoninya. Di sisi lain, masing-masing komunitas atau kelompok negara imperalis telah memilki agendanya. Spanyol dan Portugis, telah mengawalinya, kemudian disusul Inggris, Belanda dan Amerika di kemudian hari ikut masuk ke wilayah utara Kalimantan dan sekitarnya. Selain sebagai wilayah penanaman ideologi, sebagaimana Spanyol dengan Perang Salibnya, atau dikuasai sebagai daerah pemasaran produksi, seperti dilakukan oleh Inggris, serta ada upaya eksploitasi kekayaan alam yang memang kaya sumber alamnya, membuat wilayah ini terpecah belah dan saling curiga. Belanda cukup jeli memanfaatkan keadaan, dan pada penghujung abad ke- 18 Masehi penguasaan tambang minyak bumi atas Pulau Tarakan dan Pulau Bunyu diawalinya dengan melemahkan kekuasaan politik dan legitimasi Kesultanan Bulungan.

Dalam keadaan dualisme keturunan silsilah Kesultanan Bulungan, Belanda mendapat kesempatan untuk mempengaruhi pemerintahan dan situasi politiknya. Semula, kedatangan Belanda pada sekitar 1817 adalah sebagai pedagang, kemudian mulai membangun pengamanan kongsinya di
Tanjung Selor dan mempersenjatainya. Dalam situasi politik yang penuh persaingan, maka ditandatangani perjanjian kontrak politik pada tanggal 12 November 1850 yang sangat merugikan Kesultanan Bulungan dan semakin memperkokoh posisi Belanda di Tanjung Selor.

\section{E. Penutup}

Sungai Kayan merupakan sungai yang daerah hulunya berdekatan dengan batas negara, terletak di bagian utara Kalimantan. Keadaan sungai ini hampir sama pentingnya dengan Sungai Iwan, Sungai Luran, Kayan Mentarang, dan Long Brini. Menurut analisis Sellato, hal tersebut terkait dengan arus migrasi. Peran penting Sungai Kayan sebagai urat nadi perubahan dari daerah tertutup di pedalaman ke daerah hilir, mendekati pantai. Berkat sungai ini terjadilah kontak antarkomunitas, antarbudaya, dan pertukaran barang. Interaksi antarkomunitas menyebabkan kemajuan dalam peradaban, teknologi, sistem pemerintahan, dan kekerabatan, serta mulai mengenal perdagangan sebagai akibat adanya perbedaan hasil bumi. Kemajuan dan perubahan budaya pun sangat tergantung pada intensitas interaksi manusianya dan usaha penaklukan alam. Bagian utara Kalimantan, dari pesisir hingga pedalaman meninggalkan jejak arkeologi yang beragam. Peninggalan menhir, dolmen, dan kubur batu serta peninggalan lainnya merupakan informasi penting tentang arus migrasi dan merupakan studi etnografi yang penting di Kalimantan. Sellato dan Karina Arifin telah mengawalinya, tetapi akan lebih baik jika Pusat Arkeologi Nasional dan jajarannya melanjutkannya dengan penelitian secara lebih intensif. 
Pengaruh Budaya Luar terhadap Perkembangan Masyarakat Bulungan: Studi Pendahuluan 117-129

Menurut informasi masyarakat Kenyah yang sekarang mendiami daerah Sungai Bahau dan Long Pujungan, bangunan kubur tempayan dolmen (megalitik) yang banyak ditemukan di daerah ini dibuat oleh etnis Ngorek. Dari sejarah yang direkonstruksi oleh Sellato, diduga masyarakat awal ini berasal dari Sungai Baram di Serawak. Peperangan dengan etnis Kelabit menyebabkan sebagian masyarakat Ngorek berpindah ke Kalimantan bagian timur sekitar tahun 1700-1750an. Masyarakat Ngrorek mendiami daerah hulu Sungai Lurah dan Sungai Bahau. Pada pertengahan abad ke-18 Masehi, persekutuan etnis Modang, Kayan, dan Kenyah menyerang masyarakat Ngorek. Mereka kalah dan bangunan kubur tersebut diperkirakan berasal dari abad ke-17 Masehi, dan termuda dari awal abad ke-19 Masehi (Sellato 1996, 397).

Menurut Sellato, di Long Pujungan kuburan umumnya berbentuk tempayan dolmen dari batu, dengan variasi temuan menhir. Di Kerayan dikenal batu terupun dan sejenis kubur tempayan dolmen dan wadahnya berupa guci keramik serta menhir. Di Malinau, sejauh ini belum ditemukan kubur batu, terdapat kubur dari kayu/lungun, serta keramik. Di Kayan hulu, wadah kubur batu yang paling sering ditemukan berbentuk palung, persegi empat memanjang (Sellato 1995, 412 ).

Proses Islamisasi di Bulungan menyimpan kisah yang mendasar dalam mengubah sistem pemerintahan. Hal tersebut menggambarkan bagaimana terjadinya hubungan antarkomunitas, di mana masyarakat Dayak menerima atau mengadopsi pengaruh baru. Melalui proses difusi, unsur kebudayaan berubah dan berkembang. Hal tersebut juga merupakan salah satu cara dalam pengayaan identitas. Adapun pengaruh yang datang kemudian, mengusung kolonialisme, yaitu interaksi yang tidak dilandasi oleh semangat kesetaraan dan persamaan hak. Kepincangan interaksi ini terjadi karena satu pihak berkedudukan sebagai penjajah yang bersifat menguasai, pihak yang lain sebagai bangsa terjajah, yang dikuasi. Masa tersebut disebut pula sebagai era imperialisme, yang diperankan oleh Belanda dan perusahaan Inggris terhadap Kesultanan Bulungan. Jenis interaksi ini tidak lepas dari eksploitasi kekayaan alam, sebagaimana penguasaan tambang minyak bumi atas Pulau Tarakan dan Pulau Bunyu, yang diawali dengan melemahkan kekuasaan politik dan legitimasi Kesultanan Bulungan.

Sungai Kayan memiliki peran penting sebagai alur transportasi sekaligus modal perubahan. Sungai ini telah membawa semangat penaklukan alam dan menjadi lambang etos menuju kemajuan dan peningkatan harkat budayanya. Perubahan hanya dapat terjadi oleh keinginan yang kuat dari individu atau sebagian komunitas, yang tak ingin terkungkung oleh tradisinya. Di sisi lain, ada individu atau sebagian komunitas dari luar yang ingin mengobati rasa keingintahuan dan keinginan meluaskan pengaruhnya ke masyarakat lain. Datuk Mencang, seorang bangsawan Brunei dan Singa Laut menggambarkan tokoh-tokoh tersebut. Hal ini sesuai dengan pengetahuan Bangsa Eropa yang melihat Brunei sebagai kerajaan di Kalimantan pada awal abad ke16 Masehi, di samping kerajaan lainnya, yaitu Banjarmasin, Pontianak, Sukadana, dan Sambas. Bahkan nama Borneo diduga dari kata Brune, Berunai/Brunei yang dahulu merupakan suatu desa di sebelah utara Pulau 
Pengaruh Budaya Luar terhadap Perkembangan

Masyarakat Bulungan: Studi Pendahuluan 117-129

Kalimantan dan sekarang menjadi nama negara tetangga Indonesia. Kesultanan Brunei dan Kesultanan Sulu, Filipina kemungkinan telah mendapat pengaruh lebih awal Islam dari wilayah utara, dan kemudian Islam dibawa masuk melalui lintas sungai. Beratnya medan rupanya telah menghambatnya, sehingga tidak sampai ke pedalaman. Sayang sekali informasi sejarah ini belum didukung data arkeologi.

Penelian eksploratif di atas belum menjangkau seluruh permasalahan arkeologi di bagian utara Kalimantan. Usaha tersebut perlu dilanjutkan ke dalam penelitian yang lebih intensif, sehingga dapat menjawab permasalahan migrasi, keragaman budaya serta etnoarkeologi.

\section{Referensi}

Anonim. 1976. Monografi daerah tingkat II Bulungan. Jakarta: Proyek Pengembangan Kebudayaan. . 2010. Bulungan dalam angka Bulungan: Badan Pusat Statistik Kabupaten Bulungan.

Arianto, Sugeng. 2003. Kerajaan Bulungan 1555-1959. Skripsi. Malang: Fakultas Sastra Universitas Negeri Malang.

Atmojo, Bambang Sakti Wiku. 2000. Penelitian arsitektur makam raja-raja di Kesultanan Bulungan dan Berau, Kalimantan Timur. Laporan Penelitian Arkeologi. Banjarbaru: Balai Arkeologi Banjarmasin.

Arifin, Karina dan Bernard Sellato. 1999. Survai dan penyelidikan arkeologi di empat kecamatan Long Pujungan, Kerayan, Long Mentarang, Malinau, dan Kayan Hulu. Jakarta: Ford Foundation.
Eghenter, Ed dan Bernard Sellato. 1999. Kebudayaan dan pelestarian alam, penelitian interdisipliner di pedalaman Kalimantan. Jakarta: The Ford Foundation.

Gunadi. 2006. Penelitian arkeologi prasejarah di Kabupaten Malinau, Kalimantan Timur. Banjarbaru: Balai Arkeologi Banjarmasin.

Prasetyo, Bagyo dkk. 2004. Religi pada masyarakat prasejarah di Indonesia. Jakarta: Asisten Deputi Urusan Arkeologi Nasional.

Reid, Anthony. 2011. Asia Tenggara dalam kurun niaga 1450-1680. Jakarta: Yayasan Obor.

Susanto, Nugroho Nur. 2012. Penelitian eksplorasi di Kabupaten Bulungan, Kalimantan Timur. Laporan Penelitian Arkeologi. Banjarbaru: Balai Arkeologi Banjarmasin. Belum diterbitkan. 